\title{
Good Governance and Service Delivery: A Study of Citizen Participation in Kisumu County
}

\author{
Kimutai, Gilbert Kiplimo ${ }^{1, *}$, Aluvi Patrick Amisi ${ }^{2}$ \\ ${ }^{1}$ School of Development and Strategic Studies, Maseno University, Kenya \\ ${ }^{2}$ Department of Humanities and Social Sciences, University of Kabianga, Kenya
}

Copyright $\mathrm{O} 2018$ by authors, all rights reserved. Authors agree that this article remains permanently open access under the terms of the Creative Commons Attribution License 4.0 International License

\begin{abstract}
Citizen participation is embedded in the Constitution of Kenya 2010 and the County Governments Act of 2012. The responsibility of operationalizing and implementing these provisions lies with both levels of government. Citizen participation is the process through

interference, low turnout in government functions and lack of adequate understanding of government procedures among the community members. The findings suggest that civic education must be intensified to increase the scale and quality of public participation in Kisumu County.
\end{abstract} which stake holders input and share control over development initiatives, decisions and resources which affect them. Strengthening citizen participation is a key focus of Kenya's devolution under the constitution and legal framework. This ambitious devolution shifts some key decision making from central to county governments creating a window of opportunity for more "bottom-up" engagement backed by a constitutional and legal framework that include provisions for government to share information, consult the public and regularly gather citizen feedback. Although counties are mandated to facilitate public participation, the actualization and subsequent impact of this aspect of good governance on service delivery is a matter of public debate. This paper sought to investigate the influence of citizen participation in governance on service delivery in Kisumu County. Its objectives were to examine the existing avenues available for citizen participation, to assess the extent of citizen participation in governance in Kisumu County, to examine the challenges hindering effective citizen participation and to assess the contribution of citizen participation in promoting good governance and service delivery in Kisumu County. A sample of 112 respondents was selected for the study. These included 42 county government officials and 70 local residents purposefully selected for the study. Data was collected through interviews, collated and presented in tables and discussions. The findings of the study indicate that public participation has been largely entrenched in key government roles in Kisumu County. The input of the public is sought and co-opted at every stage of the project cycle. The study established that this participation has enhanced public ownership of government projects and promoted accountability. However, the scope and effectiveness of public participation in the County has been hampered by political
Keywords Good Governance, Citizen Participation, Service Delivery, Devolution

\section{Background of the Study}

The principles of democratic governance provide an opportunity for citizens to see themselves not only as sovereign citizens, enjoying a rich and broadened Bill of Rights, but more particularly as free citizens constructing their destinies. This requires a deeper understanding and appreciation of democratic space, role of citizens and responsibilities of both National and County governments in development. Public participation in political processes is viewed by scholars and democrats as a virtue in its own right and a fundamental dimension of democracy. A healthy democracy is generally seen as one in which the citizens participate regularly in formal political activities, despite the lack of agreement among scholars about the required nature and degree of participation [1].

Diamond, Linz \& Lipset [2] define a democratic system as one in which there is meaningful and extensive competition among individuals and organised groups, especially political parties, for all effective positions of government power through regular, free and fair elections that exclude the use of force; a highly inclusive level of political participation in the election of leaders and policies, such that no major (adult) social group is prevented from exercising the rights of citizenship; and a level of civil and political liberties - freedom of thought and expression, freedom of the press, freedom of assembly and demonstration, freedom to form and join organisations, freedom from terror and unjustified imprisonment - 
secured through political equality under a rule of law, sufficient to ensure that citizens (acting individually and through various associations) can develop and advocate their views and interests and contest policies and offices vigorously.

Huber, Rueschemeyer \& Stephens [3] insist upon a fourth dimension of democracy, involving: '[a]ccountability of the state's administrative organs to the elected representatives' (which we might note interlocks with electoral and party competition, given that elections constitute an opportunity for electorates to hold representatives accountable.

According to Governance Pro [4], good governance has eight major characteristics. It is participatory, consensus oriented, accountable, transparent, responsive, effective and efficient, equitable and inclusive, and follows the rule of law. It assures that corruption is minimized, the views of minorities are taken into account and that the voices of the most vulnerable in society are heard in decision making. It is also responsive to the present and future needs of society.

In recent years, citizens in many countries have been on the receiving end of a wave of interest from governments, NGOs, donors and lenders in ways of involving them more actively in shaping decisions that affect their lives. Innovative experiments in governance have opened up spaces for public involvement in deliberation over policies and a greater degree of control over certain kinds of resources $[5,6]$. Levering open arenas once closed off to citizen voice or public scrutiny, these moves have helped to widen political space for citizens to play more of a part in shaping some of the decisions that affect their lives. Forms of political participation associated with liberal democracy have come to be complemented with a new architecture of democratic practice, built on familiar foundations and offering ambiguous new political opportunities. Whether in budgeting, policy dialogue, planning, project appraisal, poverty assessment, monitoring or evaluation, 'participatory' alternatives to expert-driven processes has gained ground. These moves have given rise to new interactions and institutions, blurring old boundaries and creating new configurations of power and resistance.

Kenya enacted a new constitution in 2010 in line with this global aspirations and developments. Participation by the citizens is considered a key cornerstone of good governance and is included as one of the national values and principles of governance under article 10 of the Constitution of Kenya 2010[7]. These values and principles bind all state organs, state officers, public officers and all persons in interpreting and applying the constitution and laws and implementing policy decisions.

Odhiambo and Taifa [8] define citizen participation as the process through which stakeholders input and share control over development initiatives, decisions and resources which affect them. Okello and Chege [9] understand it as a process whereby stakeholders influence policy formulation, alternative designs, investment choices and management decisions affecting their communities.
Yang and Callahan [10] argue that participation could be either direct or through legitimate intermediate institutions or representations. Indirect involvement acknowledges that electoral officials and professional administrators should act on behalf of the citizens in a representative democracy. Direct involvement suggests that citizens are the owners of the government and should be involved in decisions of the state.

\section{Elements of Citizen Participation}

Citizen participation is expected to ensure the protection of rights, transparency, accountability, equity, self-determination influencing decision making, effective democratic citizenship and meaningful dialogue as discussed below:

\section{Citizen Participation as a Right}

According to the National Democratic Institute [11], citizens have a set of rights and responsibilities including the right to participate in decisions that affect public welfare. The composition of citizen participation formations are more effective when they draw upon civic commitments of ordinary citizens, representative interests of County Assembly members, technical County government officers, CSO representatives, religious and development partners. To this particular extent the argument is that citizen participation formations should be demographically representative and socially inclusive of all stakeholders and thus should cut across youth, women, retired professionals, marginalized groups and faith based organizations who offer more civic value-based contributions to upholding community interests.

This is expected to be the surest way to enhance coordination, joint learning and knowledge sharing among citizens, and also to enhance quality and coherence in policy advocacy. This is more particularly so if the task of enhancing the capacity of the communities and government personnel in embracing and utilizing participatory approaches remains a core pillar of good governance.

\section{Citizen Participation and Transparency}

According to Blackburn, [12] Sabatier [13] and Yankelovich [14] citizens who receive quality feedback and responsiveness when interacting with government through public participation are likely to perceive that they gain useful policy information that helps them to better understand government agencies and community issues.

The right of access to information and the transparency that comes with it underpin two distinctive yet mutually reinforcing principles of democratic governance: publicity of citizen action and transparency of public administration. It is the strategic conflation of these into a unified scheme 
of democratic social praxis and relations that completes the circle of citizen participation and participatory/open government. Participation is anticipated to enhance the transparency of interaction in the public domain through such facilities as notice board announcements of job opportunities, recruitments information; social/ participatory budgeting; opening the budget process to citizen participation; procurement transparency and oversight committees (part of which will be the requirement that procurement records, including a detailed contractor/supplier profile be made available to the public); monthly revenue and expenditure reports; quarterly development status reports; bi-annual monitoring report prepared through the Sub-County Citizen Forums; County and Sub-County Assemblies; monthly public revenue and expenditure forums; and quarterly face-to-face question and answer sessions with the governor and senator of each County.

\section{Citizen Participation and Accountability}

In public sector leadership roles, accountability amounts to the acknowledgment and assumption of responsibility for actions, decisions, policies and outcomes. This includes the administration, governance, and implementation within the scope of the role encompassing the obligation to own up, report, explain and be answerable for the consequences.

\section{Citizen Participation and Transparency}

Freedom of information is the cornerstone to good governance, meaningful participation, and efficiency-enhancing transparency. It is, therefore, recognized by a broad majority of the people as a fundamental human right without which the claim on and the exercise of democratic citizenry and upholding of democratic values of equality and justice remain a pipedream. Sustainable democracy, therefore, depends on a knowledgeable citizenry whose access to a range of information enables it to participate more fully in public life, helps to determine priorities for public spending, receives equal access to justice, and holds its public officials accountable and for that matter more responsive to the social development needs of the entire population.

Inadequate access to public information allows corruption to flourish and breeds unequal access to public resources; and since politics, at its most basic level, is about resource distribution decisions and, for that matter, the red meat of politics, lack of transparency in public affairs is, therefore, a recipe for the dark forces in society to insinuate their malign influence over the development of appropriate social capital. The benefits of such social capital can only be maximized if it is sustained by efficient management of knowledge as a conflated product of free, accessible, accurate and timely information.

As an imperative of good governance, transparency is provided for in the Constitution by the requirement for County Assemblies to conduct their business in an open manner, to hold sittings of their committees in public and to facilitate public participation and involvement of citizens (Article 196) (1) (a) (b) in matters of public interest. Budget literacy, not only among the elite stakeholders in the urban areas, is a key ingredient of effective citizen participation.

\section{Citizen Participation and Equity}

Equity in its prescriptive usage, and as the ideological underpinning of democratic governance, has a close connection with ethics, morality and justice, in general, and distributive justice in particular. From antiquity onward and for all societies on earth, equality has been considered a constitutive feature of justice. The presumption of equality is a prima facie principle of equal distribution for all goods politically suited for the process of public distribution. In the domain of political justice, all members of a given society, taken together as a collective body, have to decide democratically on the fair distribution of social goods. Applied to our political situation and domain, the presumption of equality requires that everyone, regardless of tribal, gender, religious, generational and regional differences, should get an equal share in the distribution of public resources including, public infrastructures, employment opportunities and capacities (Article 10. (2)(b).

\section{Citizen Participation and the Right to Self Determination}

Citizens are part of a given society as self-actualizing individuals. It begins with the assumption that people are active organisms, with evolved tendencies toward growing, mastering ambient challenges, and integrating new experiences into a coherent sense of self. The natural tendency towards self-determination does not, however, operate automatically and certainly not in a vacuum, but instead requires on-going social interactions and available social nutriments and support systems. That is, the social context can either support or thwart the natural tendencies toward active engagement and civic growth, or it can catalyze lack of integration, defense, and fulfillment of need-substitutes. Thus, it is the dialectic between the active/participative citizen and the social context that is the basis for self-determination.

Self-determination requires a democratic space for citizen engagement for its realization. Within self-determination, the nutriments for sovereignty and the accompanying self-actualization and functioning are specified using the concept of social-psychological needs for relative autonomy, social competence, and relatedness. To the extent that the needs of self-determination are continuously satisfied, citizens are more than likely to 
grow into well-adjusted members of a given society; but to the extent that they are thwarted or starved of democratic instrument for effective participation, the people are more than likely to be disposed towards social anomy, ill-being and non-optimal functioning. The darker sides of human behavior and experience, such as certain types of psychopathology, prejudice, and social aggression are understood in terms of reactions to deficits in such basics as self-actualization having been thwarted.

\section{Public Participation and Decision Making}

The process and act of influencing decision making by citizens presupposes that:

- Rule-making behavior by public authorities is subject to inputs by citizens for purposes of popular ownership and free-willed fealty to the outcomes of the decision making in question,

- It is mandatory as a means of improving the legitimacy and binding authority of decision making and its outcomes,

- It removes the formalistic trappings of democracy and essentially disciplines the practice of it thereby making it a way of life rather an imposition by the whims of a patrimonial state.

- It promotes and protects inclusivity in the public life of a community rendering it the only viable basis of democratic citizenship built on the imperative of equity.

The Constitution of Kenya provides for the participation of the public in the exercise of the powers of the state and in making decisions through indirect and direct involvement of the people in the process of policymaking (Article 232. (d) and participation in the legislative business of the National Assembly, Senate and County Assemblies (Article 118 (1) (a) (b), 124.(1) (b), 124. (4) (c), 196. (1) (a) (b).

\section{Citizen Participation and Meaningful Dialogue}

It is only through open and appropriate deliberative processes that the legitimacy of decision-making will justify binding policy action. This requires the creation of autonomous democratic spaces in which citizens can freely process their social demands and, as a necessary consequence, engage public authorities in making sure that the outcomes of such processes resonate deeply with their social development needs. This should end up turning them into architects of their own destinies and makers of their own history.

\section{Citizen Participation in Kisumu County}

From the foregoing, it is apparent that a lot of relevance is attached to the significance of public participation in governance and service delivery. This paper will focus on the particular case of Kisumu County in Kenya and on direct participation which is administrative centric. This means that it focuses on the role of the public in the process of administrative decision making and management processes as anticipated in the Constitution of Kenya 2010.

Kisumu County is one of the 47 Counties in Kenya lying within longitudes $33^{\circ} 20^{\prime} \mathrm{E}$ and $35^{\circ} 20^{\prime} \mathrm{E}$ and latitudes $0^{\circ} 20^{\prime}$ 'South and $0^{\circ} 50^{\prime}$ 'South. The County is bordered by Homa Bay County to the South, Nandi County to the North East, Kericho County to the East, Vihiga County to the North West and Siaya County to the West. The County covers a total land area of $2009.5 \mathrm{KM}^{2}$ and another 567 $\mathrm{KM}^{2}$ covered by water.

Kisumu County has seven constituencies namely; Kisumu West, Kisumu Central, Kisumu East, Seme, Muhoroni, Nyando and Nyakach. Each constituency is represented by a member of parliament. The County assembly currently has thirty five (35) elected representatives and fourteen (14) nominated representatives. The County has an executive committee made up of the Governor, his Deputy and the Chief Officers.

According to 2009 National Census Kisumu County has a population of 968,909 . The population density is 465 persons per $\mathrm{Km}^{2}$. The population distribution by sex is 474,756 male and 494,153 female (2009 Kenya Population and housing census). The County has a total of 997 Early Childhood Development (ECD) centres and a total of 655 primary schools. There are 158 secondary schools in the County. Other educational institutions in the county include 3 universities, 5 university campuses, 1 national polytechnic, 1 medical training college and Kenya Utalii College Kisumu Campus.

The County has a diverse economic potential. It sits on the shores of Lake Victoria, thus providing it with the potential to be a major fishing spot. Agriculture is another area of potential. Rice is grown under irrigation in the Kano plains. Most of the water for irrigation comes from river Nyando, whose annual floods displace huge numbers of people. Kano plains also hosts sugarcane fields that supply Kibos, Muhoroni and Chemelil sugar factories located within the County.

Kisumu County also has unique features such as the shoreline of Lake Victoria, Kit Mikayi, Ndere Island National park (which hosts an amazing variety of wildlife), Impala Park among others which collectively make Kisumu a major tourist destination. The Kisumu international Airport now has the potential to deliver international tourists directly into the county.

The city of Kisumu was founded as a terminal for the railway and hosts a big railway station, thus linked to other towns along the railway line. The Lake also links the County not only with three other lakeside counties but also 
with the countries of Tanzania and Uganda. As such, the port of Kisumu despite being inactive at the moment has the potential to become a regional Centre of Lake Transport and a gateway for Kenya into the rest of the African Great Lakes region.

Kenya's devolution is among the most ambitious in the world transferring key functions and financing to an entirely new level of sub-national government. Strengthening public participation is a key focus of the new constitutional and legal framework. This ambitious devolution shifts some key decision making from central to county governments creating a window of opportunity for more "bottom-up" engagement backed by a constitution and legal framework that include provisions for the government to share information, consult the public and regularly gather citizen feedback.

Citizen participation in administrative decision making is inclusive of goal setting, determination of strategies, policies and monitoring and evaluating government services. Citizen participation would then relate to the techniques and mechanisms to arrive at these. Theoretically, these techniques include but are not limited to public hearings and sittings, citizen advisory councils and citizen panels, neighborhood or resident association meetings and surveys. The functional and practical areas for citizen involvement are economic development, education, environmental protection, public health and policing and public safety among others [15].

Although counties are mandated to facilitate public participation, they face challenges such as how to engage disadvantaged communities especially in marginalized areas including arid and semi-arid regions. The actualization and subsequent impact of this critical component of good governance in promoting effective and efficient service delivery remains a matter of public speculation and debate. This paper sought to assess the extent of citizen participation in governance in Kisumu County and to crystallize its actual impact on service delivery.

\section{Objectives of the Study}

The overall objective of the study was to assess the effect of citizen participation on governance and service delivery in Kisumu County. Specifically, the study sought addresses the following objectives:

i To assess the extent of citizen participation in governance in Kisumu County

ii To identify the existing avenues for citizen participation in governance in Kisumu County

iii To examine the challenges that have hindered effective citizen participation in Kisumu County

iv To assess the contribution of citizen participation to service delivery in Kisumu County.

\section{Methodology of the Study}

A case study method was employed in the study. Data collection instruments used was interview schedules and documentary review. The target population was 968,909 from the entire county. However, 112 respondents were selected purposefully for the study. The data was obtained collated and presented in discussions.

Table 1. Distribution of Sampled Population

\begin{tabular}{|c|c|c|}
\hline S/no. & Category & Number \\
\hline 1 & Government Officials & 42 \\
\hline 2 & Members of the Public & 70 \\
\hline & TOTAL & 112 \\
\hline
\end{tabular}

Source: Authors Research Data 2016

\section{Findings}

\section{The Extent of Citizen Participation in Governance in Kisumu County}

The study established that the citizens' involvement in governance in the county is reasonable at $50.8 \%$ and that the respondents agree that the public is involved in issues of governance in the County. All the government administrators interviewed indicated that they normally involve the public in all government initiatives. This is due to the legal and constitutional nature of this requirement. However, only $42.6 \%$ of the members of the public indicated that they had been involved. The difference in figures was explained by the finding that many times there is apathy and low turnout in government fora meant to bring on board members of the public. Therefore in as much as government officials strive to achieve complete participation, this is hampered by lack of commitment on the side of the citizens. The county government has set up mechanisms to ensure that citizen involvement is achieved in the county budgeting process, legislation, public policy making and in every project cycle.

\section{Budgeting}

The constitution requires that the citizens be involved in the budget making process. This has been realized in the county through the public fora organized to seek public opinion on the allocation and utilization of public funds. These fora are organized at the county level and they provide an important avenue for the citizenry to scrutinize the allocation and utilization of public finances. Financial bills provide an opportunity for the citizens to decide on the levels of taxation in any particular sphere.

\section{Projects}

Before embarking on any project, the county government mobilizes the residents and gives them a chance to identify and prioritize the projects that they 
desire. During project implementation, the residents of the project area are required to for Project Management Committees (PMCs) to handle project implementation, monitoring and evaluation.

\section{Formulation of Policies and County Government} Legislation

This is a process whereby the residents of the County are given a chance to add their input on policies and laws that govern their lives. The study established that the County Government provides these opportunities through inviting experts and members of the public to deliberate on bills and proposed policies before submission to the County Assembly. This process is formalized and normally conducted at the County Government headquarters in a conference model. Additionally, the County Government has devolved this pursuit of public opinion on policies and legislation to the Sub-County levels whereby the Sub-county Administrators spearhead these exercises.

\section{Annual Development Plan}

This provides a chance for the citizens to prioritize the distribution of projects to be implemented in every financial year in the various sectors, i.e. roads, health or water. It also gives the residents a chance to rank the projects in terms implementation on need basis

\section{The Existing Avenues for Citizen Participation in Governance in Kisumu County}

The respondents identified the following as the key avenues for citizen participation in governance in Kisumu County:

Table 2. The Existing Avenues for Citizen Participation in Governance in Kisumu County

\begin{tabular}{|l|c|c|}
\hline S/no. & Existing Avenues & $\begin{array}{c}\text { Percentage of } \\
\text { Respondents }\end{array}$ \\
\hline i & Key informants/point men & $33 \%$ \\
\hline ii & Public gatherings including barazas & $77.8 \%$ \\
\hline iii & Community conversations & $33 \%$ \\
\hline iv & Proposal Submission & $11 \%$ \\
\hline v & County website & $22 \%$ \\
\hline vi & $\begin{array}{c}\text { Local radio stations, Print and Electronic } \\
\text { Media }\end{array}$ & $13 \%$ \\
\hline vii & Door to door visits & $6 \%$ \\
\hline viii & School announcements & $4.8 \%$ \\
\hline ix & Debates & $1.6 \%$ \\
\hline x & $\begin{array}{c}\text { Mounting of suggestion boxes in } \\
\text { government offices/strategic places }\end{array}$ & $1.6 \%$ \\
\hline xi & Seminars and periodic trainings & $3.2 \%$ \\
\hline
\end{tabular}

Key Informants/Point Men

This is the process whereby County Government officials seek the comments and input of senior citizens and opinion leaders on key Government projects. The opinion leaders include church leaders, elders and respected community leaders. $33 \%$ of the government officials interviewed identified this as the mode of involving citizens in government projects.

\section{Public Gatherings Including Barazas}

Public gatherings act as the main platform for the County Government to announce and make public its plans, intentions and priorities. Findings in Table 2 show that $77.8 \%$ of the officials interviewed cited this as the main mode of reaching out to the citizenry. This acts as an information dissemination platform on Government projects and initiatives. Additionally, it stimulates interest and participation from the public once they are made aware of Government plans. These public gatherings also act as communication fora to invite citizens to further meetings and project planning events.

The interactive nature of public barazas allows citizens to give their feedback and publicly critique Government programs and projects.

\section{Community Conversations}

This entails conducting focused group discussions from village to village in a random manner. $33 \%$ of the respondents identified this as a mode of facilitating public participation in governance in the county. A formal focused group discussion involves the calling of selected influential persons for discussions.

\section{Site Meetings}

Site meetings at project venues provide an opportunity for members of the public to voice their contribution to the project implementation detail. This contributions and suggestions lead to project re-designation and alterations where necessary to meet the community needs.

\section{Proposal Submission}

This is the submission of proposals by the citizens on the implementation of government projects. These proposals subsequently shape the project details to the benefit of the community members. $11 \%$ of the respondents identified this as another mode of public participation in governance.

\section{County Website}

The findings in table 2 indicate that $22 \%$ of the government officials interviewed noted the county website plays a key role in facilitating citizen participation in governance in Kisumu. The county has a fully functional website. Apart from disseminating critical information the county government, the website also provides an interactive platform for the citizens to engage with the government on the issues that affect their daily lives.

\section{Private Sector/Civil Society/NGOs}

The county government engages the civil society as a critical partner in governance. Hence, the county 
government invites and embraces the research findings, comments and opinions of the civil society as the consolidated view of the citizenry. Additionally, the critique offered by the civil society becomes an important component of the participation of the society in governance.

Local Radio Stations, Print and Electronic Media

Findings in table 2 show that $13 \%$ of the respondents indicated that the media in general acts as a major avenue for public participation in governance. These media channels provide a 2-way interactive base for the county government and the public. The county government employs these media to disseminate critical information on its work and through live radio shows the public can ventilate and add their input on the county government.

\section{Other Avenues:}

The respondents proposed the following as other important avenues that the county government can employ to expand the scope and quality of public participation in governance:

- $\quad$ Door to door visits

- School announcements

$-6 \%$

- Debates

- $4.8 \%$

- Mounting of suggestion boxes in government offices/strategic places $\quad-\quad 1.6 \%$

- Seminars and periodic trainings $\quad-\quad 1.6 \%$

- Posters/fliers $\quad-\quad 3.2 \%$

The Challenges that Have Hindered Effective Citizen Participation in Kisumu County

Table 4. The Challenges that have Hindered Effective Citizen Participation in Kisumu County

\begin{tabular}{|l|c|c|}
\hline S/No. & Challenge & Percentage of Respondents \\
\hline i & Communication problems illiteracy and ignorance & $55 \%$ \\
\hline ii & Political interference & $5 \%$ \\
\hline iii & Apathy/low turnout & $40 \%$ \\
\hline iv & Corruption & $5 \%$ \\
\hline v & Expectation of pay for participation & $5 \%$ \\
\hline vi & Diverse community interests hence conflict & $6 \%$ \\
\hline vii & Impatience and expectation of instant results & $3 \%$ \\
\hline viii & Limited ownership of projects & $1.6 \%$ \\
\hline ix & Short notices of meetings & $16 \%$ \\
\hline x & Tribalism & $1.6 \%$ \\
\hline xi & Abuse of Office by public officers & \\
\hline
\end{tabular}

Source: Authors Research Data 2016 
Communication Problems, Illiteracy and Ignorance

Official government business is conducted in English and Kiswahili. Important government manuals are documented mainly in English. However, the majority of the masses are semi-literate. To effectively reach out to them, translations have to be done which compromises the pace and quality of public participation. Additionally, access to radio and other print and electronic media is limited to a section of the citizenry mainly the elite and the urban dwellers. This shuts out a majority of the citizens from participating in governance.

\section{Political Interference}

Politicians keen on achieving individual and partisan agenda distort the content and aim of public participation to suit their needs. Consequently, instead of the public giving objective and well informed input and suggestions, they end up playing into the hands of political machinations and plans. Some county government officers complained that politicians especially the MCAs interfere with their work as they seek to push for projects that they consider to "politically valuable".

\section{Apathy/Low Turnout}

This is a major hindrance to public participation. A majority of then government officials interviewed complained that members of the public rarely attend public fora organized to seek their input. At times only 30 people turn up for meetings called to consider projects that will affect thousands of residents.

\section{Lack of Understanding of Government Procedures/Regulations}

The limited understanding of the bureaucratic processes of the government affects the level and quality of the participation of citizens in Kisumu County in governance. Only the few elite are therefore left to participate in processes which exclude the masses.

\section{Corruption}

Despite the input of the public, the respondents complained that corruption seriously affects the eventual output of policies and selection of projects as the corrupt apply unorthodox means to influence government officials.

\section{Expectation of Pay for Participation}

The study discovered that members of the public due to poverty expect pay and facilitation for them to participate in government for. This is one more reason why low turnout is witnessed in public government meetings. The residents complain that they cannot afford to travel to meeting venues and therefore a majority is unwilling to participate.

\section{Diverse Community Interests Hence Conflict}

The democratic nature of public participation in government projects prioritization versus the vast number of needs in the region occasionally leads to conflict between various sectors and members of the community. The cut throat competition for project allocation at times leads to unhealthy conflict.

\section{Impatience and Expectation of Instant Results}

The involvement of the members of the public in government initiatives heightens public expectations even as some of them anticipate instant results and fulfillment of their suggestions. The subsequent 'delay' as the projects go through the normal project cycle leads to disillusionment and further apathy in subsequent public participation fora.

\section{Limited Ownership of Projects}

At times, the public still views and believes that county initiatives are 'government projects'. They therefore don't see the need to take participate on in these initiatives.

\section{Short Notices of Public Meetings}

The respondents complained that the notices issued for public meetings are usually short and random. This therefore denies them the chance to prepare well the contents of their presentations. They are also not able to properly organize their programs in order to be able to attend these events.

\section{Tribalism}

The comments and suggestions of a section of citizens considered as 'outsiders', are not taken seriously.

\section{Abuse of Office by Public Officers}

In some instances, public officials charged with collecting public opinion disregard these suggestions and conduct projects in 'their own way'. 


\section{The Contribution of Citizen Participation to Effective and Efficient Service Delivery in Kisumu County}

Table 5. The Contribution of Citizen Participation to Effective and Efficient Service Delivery in Kisumu County According to the respondents, Public participation in governance has contributed to effective service delivery in the following ways:

\begin{tabular}{|l|c|c|}
\hline S/no. & Contribution & Percentage of Respondents \\
\hline i & Increased levels of community ownership of projects hence improved success chances & $16 \%$ \\
\hline ii & Increased understanding of government projects/procedures & $1.6 \%$ \\
\hline iii & Accountability & $3.2 \%$ \\
\hline iv & Increased understanding of government projects/procedures & $1.6 \%$ \\
\hline v & Improves completion chances of projects & $3.2 \%$ \\
\hline vi & Opportunity to interrogate government performance and to question anomalies & $1.6 \%$ \\
\hline vii & Increased reception of government initiatives/projects & $1.6 \%$ \\
\hline viii & Less complains and more satisfied citizenry & $1.6 \%$ \\
\hline ix & Increased appreciation of government as their priority needs are met & $3.2 \%$ \\
\hline x & Efficiency in the use of national resources & $3.2 \%$ \\
\hline xi & Generation of better ideas/alternatives & $1.6 \%$ \\
\hline xii & Positive impact on living standards & $3.2 \%$ \\
\hline xiii & Improved citizen-government interaction & $3.2 \%$ \\
\hline xiv & Empowered public & $4.8 \%$ \\
\hline xv & Improved awareness of government programs & \\
\hline
\end{tabular}

Source: Authors Research Data 2016

Increased Levels of Community Ownership of Projects Hence Improved Success Chances

According to the respondents, the involvement of the public in government initiatives has heightened the level of ownership and hence improved chances of success.

Increased Understanding of Government

Projects/Procedures

Through public participation, the citizenry has been more enlightened on issues on constitutional matters and issues of governance.

\section{Accountability}

This is one of the major accomplishments of public participation. The open and public nature of government procedures including in project identification and implementation has opened up the government to greater scrutiny and hence accountability. The public can question procedures and circumstances surrounding every government action an make concrete suggestions on the issues of governance. This has reduced the chances of corruption, embezzlement of public funds and other unethical activities.

\section{Improves Completion Chances of Projects}

According to respondents, the nature of public participation whereby citizens form project committees to oversee the project cycle has enhanced the chances of project completion. This is due to the fact that the project consumers who understand their needs are the ones in charge and therefore completion of these projects is in their own interest. The respondents further highlighted that this involvement limited the initiation of new ones until the old ones are completed.

Opportunity to Interrogate Government Performance and to Question Anomalies

Public participation has offered a chance to members of the public to critique government performance and hence enhanced the quality of governance in the county.

\section{Increased Reception of Government Initiatives/Projects}

The entry of government to the community through the members of society has enhanced the level of the reception of these initiatives.

\section{Less Complains and More Satisfied Citizenry}

The study established that public participation offers opportunities at the grassroots level for citizens to air their grievances. These concerns are addressed in the life of the project cycle and hence diminishes the chance of complains once the projects are completed.

\section{Increased Appreciation of Government as Their Priority} Needs are Met

The awareness of government initiatives created by public participation has increased the appreciation levels of government efforts. Additionally, this appreciation is noted as the government addresses the priority needs of the community as they are identified by the same communities through their participation in governance. 


\section{Efficiency in the Use of National Resources}

The respondents indicated that public participation has improved efficiency in the utilization of national resources because the citizens are given an opportunity to identify the sectors where the need is felt the most and the best way to implement government projects.

Generation of Better Ideas/Alternatives

A section of the respondents highlighted that the participation of a broader section of the society increases the number of ideas and provides the best alternatives for the resolution the problems facing the community in Kisumu.

Positive Impact on Living Standards

According to the respondents, ever since public participation was entrenched in the processes of the county government, there has been a notable improvement in development levels in the county. The respondents cited projects ranging from roads, water to health facilities initiated through consultation and successfully implemented under their watch as tangible evidences of improved living standards.

\section{Improved Citizen-Government Interaction}

Some respondents indicated that public participation has indeed become a critical window for the public to engage with the county government. The formerly 'unfriendly' and 'inaccessible' government is now available and approachable. This has enhanced the citizens' sense of self-worth and bolstered their patriotic feelings.

Empowered Public

The constant awareness and exposure of the public to government procedures and activities has created an enlightened populace that can critically follow up on government initiatives. Although this is still limited in scope, its growing gradually as citizen participation is sustained.

Improved Awareness of Government Programs

The involvement of the citizens in governance has increased their levels of knowledge and awareness of government programs and procedures. This in turn has produced people who are able to offer positive and informed suggestions on government projects and thus improved service delivery.

\section{Conclusions and Recommendations}

It is apparent from the study findings that the county government of Kisumu has embarked on meeting the constitutional and legal requirements of citizen participation in governance as per the County Government Act 2012 [10] section 87. It is also evident that citizen participation is the key in improving the quality of governance and enhancing public service delivery. It is important for the county government in collaboration with the national government and other private sector entities to step up civic education on this crucial ingredient of good governance. In addition it is important that the challenges identified above are addressed by the relevant bodies at both county and national government.

Financial support for citizen participation should be a collaborative effort among all the key stakeholders, with public resources playing a key role. In this particular respect, the County government should partner with the private sector and citizens in funding citizen participation. This should be done as a matter of obligation rather than as a means of insinuating a controlling hand into the domain of citizen participation.

In order for accountability to be real, effective enforcement mechanisms must accompany the policy frameworks, statutory provisions and by-laws that will be required to anchor it within the domains of binding rules, the infringement of which will attract deterrent actions by legitimate authorities on behalf of the people but not for tendentious political competition.

\section{REFERENCES}

[1] Houston, G, R Humphries \& I Liebenberg (eds). 2001. Public Participation in Democratic Governance in South Africa. Pretoria: Human Sciences Research Council.

[2] Diamond, L, J Linz \& S M Lipset (eds). 1995. Politics in Developing Countries: Comparing Experiences with Democracy 2nd edition. Boulder, Co: Lynne Rienner Publishers.

[3] Huber, E, D Rueschemeyer \& J D Stephens. 1997. 'The Paradoxes of Contemporary Democracy: Formal, Participatory and Social Dimensions'. Comparative Politics, April.

[4] Good Governance Pro. Eight Elements of Good Governance. Available from: www.governancepro.com/news/. Accessed $14^{\text {th }}$ December, 2017

[5] Fung, Archon and Eric Olin Wright, 2001, Politics and Society. Sage Publications Inc.

[6] Goetz, Anne-Marie and Gaventa, John, 2001, Bringing Citizen Voice and Client Focus into Service Delivery, IDS Working Paper, 138, Brighton: IDS.

[7] Republic of Kenya. The Constitution of Kenya. Nairobi: Government Printer; 2010

[8] Odhiambo and Taifa. Devolved Funds and Development: A Handbook on Participation. Volume 1. Claripress; 2005

[9] Okello, M., Oenga, I. \& Chege P (2008). Participatory Urban Planning Toolkit Based on The Kitale Experience: A guide to Community Based Action Planning for Effective 
Infrastructure and Services Delivery. Nairobi: Practical Action; 2008

[10] Yang and Callahan. The Transitional Authority (2016) Transition to Devolved Government in Kenya 2012-2016. The End Term Report. Nairobi: Transition Authority; 2005

[11] National Democratic Institute. Citizen Participation. Available from: www.ndi.org. accessed $14^{\text {th }}$ December, 2017

[12] Blackburn, Walton. J., and Willa M. B. Mediating
Environmental Conflicts: Theory and Practise. Westport, CT: Quorum Books; 1995

[13] Sabatier, Paul A. An Advocacy Coalition Framework of Policy Changes and the Role of Policy-Oriented Learning therein. Policy Sciences 21, 2/3 1988, 129-168

[14] Yankelovich, Daniel. Coming to Public Judgment. Syracuse: Syracuse University Press; 1991

[15] Republic of Kenya. The County Governments Act 2012. Nairobi: Government Printer; 2012 